\title{
People's People with Sexual Behavior in Street Children
}

\author{
Kusumastuti ${ }^{1}$, Herniyatun ${ }^{2}$, Fifi Agustin ${ }^{3}$ \\ ${ }^{1,2,3}$ Department of Health, Universitas Muhammadiyah Gombong, Indonesia
}

\begin{tabular}{l} 
ARTICLE INFO \\
\hline Article history: \\
DOI: \\
10.30595/pshms.v2i.241 \\
Submitted: \\
December 6, 2021 \\
Accepted: \\
January 21, 2022 \\
Published: \\
January 26, 2022
\end{tabular}

Keywords:

Street Children; Sexual Behavior; Peers

\begin{abstract}
Street children are children who are excluded, marginal, and excluded from the treatment of affection. Until now the number of street children in Indonesia continues to decline. In 2015 there were 33,400 children, in 2016 there were 20,719 children and in 2017 there were 16,416 children. Objective this research to determine the relationship of the role of peers with sexual behavior in street children. This research used a descriptive correlation method with cross-sectional approach. Data analysis used frequency distribution analysis, Kendall's tau_b with a significance level of 5\%. There results was a relationship between the role of peers and sexual behavior as indicated by Kendall's tau_b calculation, obtained by Sig. $(2$-tailed $)=0.013$ $<0.05$, . The role of peers in street children in the Karanganyar region was in the bad category of 9 respondents $(63.3 \%)$, and for sexual behavior in street children in the Karanganyar region in the bad category there were 12 respondents (40\%). This conclusion is a relationship between the role of peers and sexual behavior as shown by Kendall's tau_b calculation, obtained Sig. $(2$-tailed $)=0.013<0.05$, a sign that there is a relationship between the role of peers and sexual behavior in street children in the Karanganyar region. Recommendation for further researchers, they can research other factors that influence sexual behavior in adolescents and add more samples.
\end{abstract}

This work is licensed under a Creative Commons Attribution 4.0 International License.

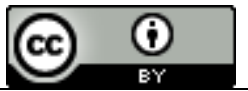

\section{Corresponding Author:}

Kusumastuti,

Department of Health, Universitas Muhammadiyah Gombong,

Yos Sudarso Street No. 461, Gombong, Kebumen, Central Java, Indonesia

Email: ncuz.kusuma26@gmail.com

\section{INTRODUCTION}

Adolescence is a period of transition from the sexual behavior of children to adults. In this situation, adolescents are more influenced by group behavior, thus showing risky behavior including those that carry the risk of early marriage. If it is not based on sufficient knowledge, adolescents will try new things related to reproductive health that can have a bad impact on the future of adolescents and their families [1].

Adolescence is a period full of problems, adolescence is a time of storm and pressure or stress. It is said that adolescence is known as the period of seeking self-identity, namely the phase where individuals experience emotional changes accompanied by varied psychological growth. The attitude of adolescents is the beginning of the emergence of problems in adolescent reproductive health. Adolescent sexual attitude is a sexual response given by someone after hearing, viewing pornographic pictures.

At this time, many teenagers who are separated from their families prefer to live on the streets with their friends. Until now the number of street children in Indonesia continues to decline. In 2015 there were 33,400 children, in 2016 there were 20,719 children and in 2017 there were 16,416 children. The highest number of street children is in DKI Jakarta with 7,600 children, followed by West Java, Central Java with 5000 children. The decline in the number of street children in Indonesia is commendable, but although the population of street children decreases every year, efforts must be made so that the number of street children continues to decrease and adolescents do not use the streets as a place to earn a living and activities that are not useful. 
In Kebumen Regency, especially in the Karanganyar area, many street children are living together under the same roof as male street children and female street children. The majority of street children are young people who want to show their identity, leaving their family, environment, and school. In dealing with street children in the Karanganyar area, the Kebumen Civil Service Police Unit (Satpol PP), the Mental Health Salter of the Pejagoan Health Center, and the Dispermades of Kebumen, especially the Women and Children Protection Sector, have committed to fostering and returning them to their families. Based on the Child Protection Law. Articles 4 to 19, every child has the right to live, the right to obtain health services, and the right to obtain social security.

The habit of a teenager who lives on the streets and is influenced by his peers is very risky for unhealthy sexual behavior. The existence of peers can affect the behavior of children. Teenagers tend to communicate more with their friends than their parents. Friends become the main source of saving sexual problems. Adolescents make their peers the first to know what is happening to them. The influence of peers can be in the form of positive support or negative support.

Peers become a reinforcing factor for the formation of behavior in adolescents, including sexual behavior. The peers have a very dominant contribution from the aspect of influence and modeling regarding sexual behavior with their partners. According to research states that there is a relationship between peer influence and the sexual behavior of a teenager with his partner [2].

Sexual behavior, especially in adolescents, is very concerning. The form of a person's sexual behavior starts from holding hands, hugging, making out, touching sensitive body parts. Sexual in general is something related to the genitals or matters relating to intimate relationships between men and women. Meanwhile, that sexual behavior is behavior that is driven by a sexual desire both with the opposite sex and the same sex [3]

According to the Center for Disease Control (CDC) in a study conducted on several high school students in the US in 2011, about $47.4 \%$ of students had sexual intercourse. Meanwhile in Indonesia, the results of the Indonesian Adolescent Reproductive Health Survey in 2012 found that $29.5 \%$ of boys and $6.2 \%$ of girls had touched or stimulated their partners, $48.1 \%$ of boys and $29.3 \%$ of girls had have kissed on the lips, and $79.6 \%$ of boys and $71.6 \%$ of girls have held hands with their partner.

Sexual intercourse can lead to an increase in sexually transmitted diseases due to an unhealthy lifestyle, causing risky infectious diseases such as syphilis, genital herpes, and HIV/AIDS. People who are exposed to HIV will become vulnerable to opportunistic infections. Although existing treatments can slow down the rate of development of the virus, this disease is not yet completely curable. HIV/AIDS cases are ranked first in Indonesia, especially in the provinces of East Java and DKI Jakarta. Most cases of HIV/AIDS occurred at the age of 25-49 years with a total of $69.2 \%$ followed by the age group of 20-24 years with a total of $16.7 \%$ and the age group of $>50$ years with a total of $7.6 \%$.

The role of peers in adolescent sexual behavior, especially street children, affects. According to research with the title Factors Affecting Sexual Behavior in Street Children Adolescents at the Girlan Nusantara Sleman Foundation, there is a relationship between the level of sexual development factors on the sexual behavior of street children adolescents at the Girlan Nusantara Sleman Foundation [4]. Meanwhile, according to Selfrina's research (2016) with the title Factors Related to Sexual Behavior at Risk of Infectious Infections in Street Children In Semarang City, there are 5 factors related to sexual behavior at risk of sexually transmitted infections in street children, namely long time on the road, consumption of addictive substances, attitude related to sexuality, peer support and peer sexual behavior. According to Rika's research (2017), entitled Relationship of Mass Media Exposure, Role of Peers to Sexual Actions At SMA AN-NAAS there is a significant relationship between exposure to mass media and sexual acts, while the role of peers has a significant relationship between the role of peers and actions sexual [5] .

Based on a preliminary study by researchers by conducting interviews with 8 street children in the Karanganyar area, data were obtained, regarding the number of street children in the Karanganyar area as many as 30 children, besides that 8 people already have partners (girlfriends). From the results of interviews also obtained data that 8 people have had sexual behavior hugging with the opposite sex and kissing with their partners, 4 people have had sexual relations with their girlfriends. Street children said that their peers also mocked if one of the children did not have a boyfriend and had never had sexual intercourse with a partner of the opposite sex. On the other hand, street children who live in the Karanganyar area, live together with female and male street children. Based on the description above, the researcher intends to conduct research on the relationship between the role of peers and sexual behavior in street children in the Karanganyar regionResearchers conducted a preliminary study through interviews with officers and elderly people who were in that place and conducted tests using the Barthel Index. Then 4 out of 10 elderly people experience mild dependence. The results of the interview regarding the dependence of the elderly found that there were only 2 caregivers there. This shows that the number of caregivers is not proportional to the number of elderly people who are there where dependence has a relationship with efficacy and motivation. 


\section{RESEARCH METHOD}

This study uses a descriptive correlation method with a cross-sectional approach. Data analysis using frequency distribution analysis, Kendall's tau_b with a significance level of 5\%.

\section{RESULT AND DISCUSSIONS}

3.1. Characteristics of Respondents Based on age, gender, education level, parental occupation, city of origin of street children in Karanganyar area.

Tabel 1. Characteristics of Respondents Based on the age of street children in the Karanganyar area

\begin{tabular}{lll}
\hline Aged of Respondents & $\mathrm{f}$ & $\%$ \\
\hline 14 & 2 & 6.7 \\
15 & 9 & 30.0 \\
16 & 8 & 26.7 \\
17 & 5 & 16.7 \\
18 & 3 & 10.0 \\
19 & 2 & 6.7 \\
20 & 1 & 3.3 \\
\hline Total & 30 & 100.0 \\
\hline
\end{tabular}

Based on the table above, it is known that most of the respondents aged 15 years were 9 respondents (30\%), followed by respondents aged 16 years as many as 8 respondents (26.7\%), and respondents aged 17 years as many as 5 respondents $(16.7 \%)$.

Table 2. Characteristics of Respondents Based on the age of street children in the Karanganyar area

\begin{tabular}{lcc}
\multicolumn{3}{c}{ children in the Karanganyar area } \\
\hline Gender & $\mathrm{f}$ & $\%$ \\
\hline Male & 25 & 83,3 \\
Female & 5 & 16,7 \\
\hline Total & 30 & 100 \\
\hline
\end{tabular}

Based on the table above shows that most of the respondents are male as many as 25 respondents $(83.3 \%)$, while for female respondents as many as 5 respondents $(16.7 \%)$.

Table 3. Characteristics of Respondents Based on the education of street children in the Karanganyar area

\begin{tabular}{lll}
\hline Education & $\mathrm{f}$ & $\%$ \\
\hline Elementary & 11 & 36,7 \\
Junior high school & 18 & 60 \\
Senior high school & 1 & 3,3 \\
\hline Total & 30 & 100 \\
\hline
\end{tabular}

Based on the table above, it shows that most of the respondents who have a junior high school education level are 18 respondents (60\%), while respondents who have an elementary education level are 11 respondents $(36.7 \%)$, and for respondents who have a high school education level are 1 respondent $(3,3 \%)$. 
Table 4. Characteristics of Respondents Based on the occupations of street children's parents in the Karanganyar area

\begin{tabular}{lll}
\hline Parent's Job & $\mathrm{f}$ & $\%$ \\
\hline Labor & 7 & 23.3 \\
Trader & 3 & 10.0 \\
Teacher & 3 & 10.0 \\
Laborer & 1 & 3.3 \\
Pedicab driver & 1 & 3.3 \\
Digging & 1 & 3.3 \\
Tailor & 1 & 3.3 \\
Project & 1 & 3.3 \\
Driver & 1 & 3.3 \\
Farmer & 10 & 33.3 \\
Carpenter & 1 & 3.3 \\
\hline Total & 30 & 100.0 \\
\hline
\end{tabular}

Based on the table above shows that most of the respondents have parents who work as farmers as many as 10 respondents $(33.3 \%)$, followed by respondents who have parents who work as laborers 7 respondents $(23.3 \%)$, and respondents who have parents who work as farmers. 3 respondents (10\%), 3 respondents $(10 \%)$, and the rest of the respondents have parents who work as coolie, pedicab, digging, tailor, project, driver, and handyman each 1 respondent (3.3\%).

Table 5. Characteristics of Respondents Based on the education of street children in the Karanganyar

\begin{tabular}{lll}
\hline \multicolumn{3}{c}{ children in the Karanganyar } \\
Home town & $\mathrm{f}$ & $\%$ \\
\hline Cilacap & 1 & 3.3 \\
Gombong & 13 & 43.3 \\
Karanganyar & 5 & 16.7 \\
Kebumen & 6 & 20.0 \\
Klaten & 1 & 3.3 \\
Purworejo & 1 & 3.3 \\
Sruweng & 3 & 10.0 \\
\hline Total & 30 & 100.0 \\
\hline
\end{tabular}

Based on the table above shows that most of the respondents came from the Gombong area as many as 13 respondents (43.3\%), followed by respondents from Kebumen as many as 6 children (20\%), Karanganyar 5 respondents $(16.7 \%)$, Sruweng 3 respondents (10\%), Cilacap 1 respondent (3.3), Klaten 1 respondent (3.3), Purworejo 1 respondent (3.3\%).

\subsection{Characteristics of peer roles based on age, gender, education level of street children in} Karanganyar area 
Table 6. Characteristics of peer roles based on the age of street children

\begin{tabular}{lllll}
\hline Age & \multicolumn{2}{l}{ THE INFLUENCE OF FRIENDS } & Total \\
& Good & Fair & Less & \\
\hline 14 & 0 & 1 & 1 & 2 \\
15 & 0 & 5 & 4 & 8 \\
16 & 1 & 1 & 6 & 5 \\
17 & 0 & 2 & 3 & 3 \\
18 & 0 & 1 & 2 & 2 \\
19 & 0 & 0 & 2 & 1 \\
20 & 0 & 0 & 1 & 30 \\
\hline Total & 1 & 10 & 19 & \\
\hline
\end{tabular}

Based on the table above shows that the role of peers seen from the average age of the respondents has peer roles in the bad category as at the age of 16 years there are 6 respondents $(20 \%)$ who have the role of peers in the bad category.

Table 7. Characteristics of peer roles by gender of street children

\begin{tabular}{lllll}
\hline & \multicolumn{2}{l}{ THE INFLUENCE OF FRIENDS } & Total \\
& BAIK & CUKUP & BURUK & \\
\hline $\mathrm{L}$ & 1 & 9 & 15 & 25 \\
$\mathrm{P}$ & 0 & 1 & 4 & 5 \\
\hline Total & 1 & 10 & 19 & 30 \\
\hline
\end{tabular}

Based on the table above shows that the highest peer role category is peer role in the bad category, this is found in street children who have male sex with a total of 15 respondents $(50 \%)$.

Table 8. Characteristics of peer roles based on street children's education

\begin{tabular}{|c|c|c|c|c|}
\hline & \multicolumn{3}{|c|}{ THE INFLUENCE OF FRIENDS } & \multirow[t]{2}{*}{ Total } \\
\hline & Good & Fair & Less & \\
\hline Elementary & 0 & 4 & 7 & 11 \\
\hline Junior & 1 & 6 & 11 & 18 \\
\hline Senior & 0 & 0 & 1 & 1 \\
\hline Total & 1 & 10 & 19 & 30 \\
\hline
\end{tabular}

Based on the table above shows that the role of peers seen from the level of education of street children in the Karanganyar area on average has the role of peers in the bad category as many as 19 respondents $(63.3 \%)$ while judging from the level of education of street children who have the highest bad peer role are children who have a junior high school education level, namely 11 respondents (36.7\%).

\subsection{Characteristics of sexual behavior based on age, gender, education level of street children in Karanganyar area}


Tabel 9. Characteristics of sexual behavior based on the age of street children

\begin{tabular}{lllll}
\hline & \multicolumn{2}{l}{ SEXUAL BEHAVIOR } & Total \\
AGE & Good & Fair & Less & \\
\hline 14 & 1 & 1 & 0 & 2 \\
15 & 4 & 2 & 3 & 9 \\
16 & 2 & 2 & 4 & 8 \\
17 & 0 & 2 & 3 & 5 \\
18 & 0 & 2 & 1 & 3 \\
19 & 0 & 1 & 1 & 2 \\
20 & 0 & 1 & 0 & 1 \\
\hline Total & 7 & 11 & 12 & 30 \\
\hline
\end{tabular}

Based on the table above shows that sexual behavior seen from the average age of respondents has sexual behavior in the bad category as at the age of 16 years there are 4 respondents $(13.3 \%)$ who have sexual behavior in the bad category.

Tabel 10. Characteristics of sexual behavior based on the sex of street children

\begin{tabular}{lllll}
\hline & \multicolumn{2}{l}{ SEXUAL BEHAVIOR } & Total \\
& Good & Fair & Less & \\
\hline $\mathrm{M}$ & 5 & 8 & 12 & 25 \\
$\mathrm{~F}$ & 2 & 3 & 0 & 5 \\
\hline Total & 7 & 11 & 12 & 30 \\
\hline
\end{tabular}

Based on the table above, it shows that the category of sexual behavior in terms of gender is sexual behavior in the bad category, this occurs in respondents with male sex as many as 12 respondents (40\%).

Tabel 11 Characteristics of sexual behavior based on the street children's education.

\begin{tabular}{lllll}
\hline & \multicolumn{2}{c}{ SEXUAL BEHAVIOR } & \multicolumn{2}{c}{ Total } \\
& Good & Fair & Less & \\
\cline { 3 - 6 } & 3 & 2 & 6 & 11 \\
Elementary & 4 & 8 & 6 & 18 \\
Junior High & 0 & 1 & 0 & 1 \\
Senior High & 7 & 11 & 12 & 30 \\
\hline Total & & & &
\end{tabular}

Based on the table above shows that sexual behavior seen from the level of education of street children in the Karanganyar area on average has the role of peers in the bad category as many as 12 respondents $(40 \%)$ while judging from the level of education of street children who have the highest bad sexual behavior are children who have junior high school education level, namely 6 respondents $(20 \%)$.

3.4 The result of testing the hypothesis of the relationship between the role of peers and sexual behavior in street children in the Karanganyar area 


\section{Correlations}

\begin{tabular}{lllll}
\hline $\begin{array}{l}\text { The influence of friends and } \\
\text { Sexual Behavior }\end{array}$ & & & \\
\hline Kendall's tau_b & action friends & Correlation Coefficient & 1.000 & $.355^{*}$ \\
& & Sig. (2-tailed) &. & .013 \\
& & $\mathrm{~N}$ & 30 & 30 \\
& Sexual & Correlation Coefficient & $.355^{*}$ & 1.000 \\
& Behavior & Sig. (2-tailed) & .013 &. \\
& & $\mathrm{~N}$ & 30 & 30 \\
\hline
\end{tabular}

*. Correlation is significant at the 0.05 level (2-tailed).

Based on the table above shows that the results of non-parametric statistical tests using the Kendall's tau_b test obtained Sig. (2-tailed) $=0.013<0.05$, so it is accepted and it can be concluded that there is a significant relationship between the role of peers and sexual behavior in street children in the Karanganyar region.

\subsection{The Influence of Peer friends}

Peers are children or adolescents who have the same age or level of maturity [6]. Peer groups have specific orientations, values, norms, and agreements that specifically apply only to that group. Peer groups have an important role for peer groups to develop their identity.

Based on research conducted in the Karanganyar area in June 2019 the data obtained from children who have roles with peers are as follows, children who have roles with peers are 10, and children who have roles with bad peers return to 19 people. streets with the role of peers are still large, which is more than $63.3 \%$. This happens because most street children in the Karanganyar area are still influenced by the words and invitations of their peers.

Many things cause street children in the Karanganyar area to mostly have bad peer roles, including street children in the Karanganyar area living together in a rented house. This is the main trigger for a teenager to spend time together, exchange ideas and influence each other. Based on observations at the time of the study, it was also seen that street children in the Karanganyar area in carrying out activities were always together, traveled together, and chatted more with fellow street children.

Of the several causes of the influence of street children on their friends, street children spend more time with their friends than with their families. In addition, teenagers listen more to friends' suggestions in making a decision or in taking an action. This is as Condery (2008) said which explains that peer association has a big impact on adolescents because teenagers spend more time with their friends [7].

The theory also reveals that the role of peers is related to determining behavior in adolescents, especially in sexual behavior because the perception of sexual behavior is the perception of peer group norms. At the age of adolescence, a teenager relies more on friends than parents or family for support and advice. This is in line with the development of the role of adolescents in the social life of adolescents so that the demands to show a high level of conformity to peers [7].

Besides adolescents rely more on friends than their parents or family, adolescents also have strong emotional bonds with their peer group. Strong solidarity in peer association makes adolescents have a strong identity bond so that adolescents are easily influenced by their peers. Strong solidarity also makes teenagers introspect on each other's bad behavior from parental control, including by lying [3].

A teenager has a very strong determination to be liked and accepted by his peers. Adolescents are very happy when accepted and very anxious if they are removed or rejected and even belittled by their peers. Peers are teenagers who are the same age, interaction between peers plays an important role in social development. One of the important roles in peers is as a source of information about the world outside the family. A teenager gets feedback about his abilities from his peers, a teenager believes what they are doing is better [6]. 


\subsection{Sexual Behavior}

Sexual behavior is any behavior that is driven by sexual desire whether done alone, with the opposite sex, or the same sex. According to sexual behavior is behavior that aims to attract the attention of the opposite sex starting from looks, dating, seducing, and flirting. Sexual behavior is a behavior that is carried out by someone of the opposite sex or the like to fulfill mutual desires/satisfaction. Sexual behavior takes various forms such as kissing, holding hands, hugging, touching, imagining, masturbating, oral sex, and having sex with the opposite sex or the same sex [8].

Based on the results of research conducted on street children in the Karanganyar area, it was found that most of the children had bad sexual behavior status, namely 12 respondents (40\%) while the remaining 7 respondents had good sexual behavior $(23.3 \%)$, and 11 respondents had sexual behavior. sufficient $(36.7 \%)$. So it can be concluded that the sexual behavior of street children is still very concerning and is still very vulnerable to the occurrence of free sex behavior among teenagers. This happens, because street children spend more time with their friends and they live together between female street children and male street children.

According to Ririanty, M. (2011), street children with active sexual behavior are 16.9 years old or 17 years old, with the lowest age being 12 years and the highest being 21 years. This is following the results of research conducted on adolescent street children in the Karanganyar area, namely street children who have bad sexual behavior found in street children who have the age of 16 years as many as 4 respondents (13.3\%), followed by children aged 17 years there are 3 respondents (10\%) who have bad sexual behavior. According to Setyadani, A.S. (2013), street children had vaginal sex for the first time in the age range of 14-16 years. On average, street children who are found at the age of 17-18 years have often had sexual relations. The higher the age, the higher the sexual behavior of street children.

Meanwhile, sexual behavior seen from the level of education of street children in the Karanganyar area on average had the role of peers in the bad category as many as 12 respondents (40\%) while judging from the education level of street children who had the highest bad sexual behavior were children who had a junior high education level, namely 6 respondents $(20 \%)$. It can be concluded that education is one of the factors that cause a teenager to have bad sexual behavior. Street children should spend their time getting an education in school, but they spend their time on the street with various threats, such as free sex. On average, street children do not finish elementary school and do not finish junior high school (Setyadani, A.S., 2013).

\subsection{The Correlation of Peer Friends with Sexual Behavior}

Based on the results of research conducted in the Karanganyar area of 30 respondents, it shows that children who are affected by the role of peers with a bad percentage are very large, namely 19 children $(63.3 \%)$, while children who have bad sexual behavior are 12 respondents $(40 \%)$.

Meanwhile, the results of the research test using Kendall's tau_b non-parametric test obtained Sig. (2-tailed) $=0.013$, because $\mathrm{p}<0.05$, it can be concluded that there is a relationship between the role of peers and sexual behavior in street children in the Karanganyar area.

This is following the results of research conducted by Nia Yulianti (2015) in a journal entitled "Peer relationships with adolescent sexual behavior in class IX students" stating that there is a relationship between peer association and sexual behavior in adolescents. Where the p-value $<0.05$ is 0.001 . This is because children hang out more or spend time with their friends, besides that children listen more to friends' invitations, especially in sexual behavior. This is evident from the results of conversations with respondents that data shows that respondents spend more time with their friends and prefer to live with their friends.

The results of this study are also in line with the results of research by Hanifah (2012) and Ardiyanti (2012) which also revealed a relationship between the role of peers and sexual behavior in adolescents. Revealed that peers function as a place for adolescents to share and Changes in behavior occur because of the transfer of behavior between fellow adolescents [6].

Myrers also revealed that teenagers tend to invite peers as a way to be accepted in friendship or accepted in the youth association group. Myrers also explains that conformity in adolescent relationships is not just acting following the actions taken by others, but also means influencing others to perform imitating behavior to enforce group identity or social identity [9]. This is following research conducted on adolescent street children in the Karanganyar area which says that information obtained from peers determines the attitude of adolescents in sexual activity with their partners.

\section{CONCLUSION}

Based on the objectives and results of research on the relationship between the role of peers and sexual behavior in street children in the Karanganyar area in June 2019, it can be concluded that: a). The role of peers in street children in the Karanganyar area is in a bad category by 19 respondents $(63.3 \%)$. b). The 
sexual behavior of street children in the Karanganyar area is in the researched category by 12 respondents $(40 \%)$. c). There is a relationship between the role of peers and sexual behavior as shown by Kendall's tau_b calculation, obtained Sig. $(2$-tailed $)=0.013<0.05$, a sign that there is a relationship between the role of peers and sexual behavior in street children in the Karanganyar region.

\section{Acknowledgements}

Thank you to Allah SWT, Muhammadiyah University of Gombong, both parents and all comrades in arms who have helped from beginning to end.

\section{REFERENCES}

[1] Poltekkes Depkes, “Kesehatan Remaja, Problem dan Solusinya,” Jakarta: Salemba Medika, 2010.

[2] Dewi, "Hubungan Karakteristik Remaja Peran Teman Sebaya, dan Paparan Pornografi dengan Perilaku Seksual di Kelurahan Pasir Gunung Selatan Depok,” Depok, 2012.

[3] Sarwono, W.S., "Psikologi Remaja,” Jakarta: PT. Raja Grafindo Persada, 2015.

[4] Iin dan Asri, "Faktor - faktor Yang Mempengaruhi Perilaku Seksual pada Remaja Anak Jalanan di Yayasan Girlan Nusantara Sleman,” Skripsi Stikes “Aisyiyah Yogyakarta, 2012.

[5] Rika, "Hubungan Keterpaparan Media Massa, Peran Teman Sebaya Terhadap Tindakan Seksual Di SMA An-Naas," Journal Endurance, Vol 2 No 2 (124-131), 2017.

[6] Santrok, J.W., "Remaja,” Edisi 12 Jilid 3. Jakarta: Erlangga, 2013.

[7] Papalia, D.E, "Human Development,” Jakarta: Salemba Humanika, 2009.

[8] Kusmiran, E., "Kesehatan Reproduksi Remaja Dan Wanita,” Jakarta: Salemba Medika, 2013.

[9] Myers, D.G., "Psikologi Sosial,” Jakarta: Salemba Humanika, 2012. 